\title{
THE SPIRITUALITY OF PEDICAB DRIVERS: A Case Study At Trunojoyo Street Bojonegoro City East Java
}

\author{
Yogi Prana Izza \\ IAI Sunan Giri Bojonegoro \\ yogipranaizza@ymail.com
}

\begin{abstract}
This paper aims to describe the spirituality of "suburban humans" who in this case are pedicab drivers on the Trunojoyo road in Bojonegoro city. The anthropological approach is used with the focus on: the meaning and needs of spirituality for pedicab drivers, the spiritual dimension of pedicab drivers and the factors that influence their spirituality. The results of this study are expected to be input into the development and improvement of spirituality as a basic human need.
\end{abstract}

Keywords. spirituality, pedicab drivers, suburban human, human need

\section{A. Introduction}

7 oday's spirituality is so attractive to modern society since modern humans are trying to overcome the spiritual crisis they have been experiencing. This crisis according to Achmad Mubarak (2001: 27) leads people to be empty human beings. They do not know what they want, and are unable to choose their ways of life. Sociologists call it a symptom of alienation, which is caused by: (a) social change that takes place very quickly, (b) warm relations between humans have turned into barren relationships, (c) traditional institutions have turned into rational institutions, (d) homogeneous societies have turned heterogeneous, and (e) social stability has changed to social mobility.

In line with Achmad Mubarak, Zakiyah Darajat (2001: 3) and Dadang Hawari (1998: 56) state that the progress in various fields of science and technology should have brought more happiness to humans in their lives. Yet, the reality portrays the oppoite ideals of such progress. It is indeed sad reality that happiness turns out to be farther away, life is increasingly difficult and material difficulties change with mental difficulties (psychis), humans become secular and experience crises of violence. The number of people who experience depression is increasing.

This paper aims to examine the spirituality of pedicab drivers as peripheral people with three focused topics; 1 . the meaning and needs of spirituality, 2. dimensions of spirituality and 3. factors that influence spirituality. The research subjects are pedicab drivers at the Trunojoyo street in Bojonegoro city. The study is based on the assumption that the pedicab drivers represent the indicators referred to as "peripheral humans". 


\section{B. The Pedicab Drivers on Jalan Trunojoyo Bojonegoro}

The term mbambung in the Javanese language can be interpreted by living wandering or living in a way that is not necessarily direction. The mbambung people are also interpreted as humans who are marginalized or marginalized by certain interests. They are a group of people who are not cared for by their environment. Yet, specifically in Bojonegoro, the term mbambung can also be indicated to people who sleep in stores. Perhaps, it is due to the assumption that those who sleep in the stores are people who are not necessarily in the direction of their lives.

Approximately, there are eight to ten pedicab drivers at the Trunojoyo street. This number is not always constant, because they just come and go alternately. However, the "occupants" who remain in the store are five people; Jajat (58 years), Supiyo (57 years), Kusiran (59 years), Kaelan (63 years), and Poniman (50 years). ${ }^{1}$ In Bojonegoro, the pedicab drivers are not vagabonds that were not necessarily the direction of their life. They are married, have children and grandchildren, although four of them have separated from their wives and have not remarried, while one person remarried. They came from villages around Bojonegoro and surrounding cities such as Tuban and Lamongan. Because of the economic demands, they chose to work as pedicab drivers by leaving their families, relatives and sleeping in a shop or on a pedicab.

Jalan Trunojoyo in the city of Bojonegoro, is a "convenient" place for the pedicab drivers to compare with other protocol roads such as Jalan Diponegoro. Pak Kusiran said that the Trunojoyo street shop was tempered more comfortably than the shops in front of the city market, which were generally used by night masseurs. In addition, the Trunojoyo road is strategically located; 50 meters from the market, government offices, shops and schools. Pak Jajat added that the city's market activity never stopped, even stretching more crowded since 1:00 a.m., so the pedicab drivers could park their becak along the city's market entrance at around 02.30 . They are waiting for people who come home from the market to bring shopping items that cannot be transported by motorbikes.

The pedicab drivers on the Trunojoyo road began arriving in front of the Prime Yamaha Motorbike and Gardena stores at 19.00-20.00 WIB, only Poniman arrived late at around 9:30 a.m. to 10:00 p.m. The Trunojoyo road in front of the Yamaha Motorbike and Gardena Prime stores as basecamps is actually not only strategically located but also because right across the street, facing the Prime Yamaha Motorbike shop, there are practices of internal medicine specialists who are always crowded with patients. This practice starts at 9:00 a.m. to 21:30 WIB. Not infrequently, patients who finish treatment need their transportation services.

The pedicab drivers began to roll out mats, turn on mosquito coils and lock the rickshaw wheels with chains and locks at 9:00 p.m. when all the shops are closed. Morning activities for

${ }^{1}$ All are anonymous names.

Teosofia: Indonesian Journal of Islamic Mysticism, Volume 7, Number 1, 2019 
work begin at 2:30 a.m. and some are just starting when dawn arrives (around 04:30 a.m. WIB). In the morning, they generally park the rickshaw in front of the market entrance, although there are those who choose to wait for passengers at the Sumbang exit location, where the bus passengers descend. When night fell, they again gathered together with fellow pedicab drivers to take a break on the Trunojoyo road.

\section{Meaning and Needs of Spirituality for Pedicab Drivers}

\section{Meaning of Spirituality}

Spirituality is defined by various meanings according to different approaches. Dadang Hawari (2001: 23) for example, defines spirituality as an individual belief in relation to the Almighty and the Creator. Spirituality also contains the notion of human relations with God by using instruments (mediums) such as prayer, fasting, almsgiving, hajj, prayer and so on.Whereas Smith and Rayment in Gibson et al (2003) define spirituality as a condition or experience that can provide individuals with direction and meaning, or provide feelings of understanding, support, inner wholeness, or connectedness. Connectivity can be with yourself, others, the universe, God, or other supernatural powers.

Thus, spirituality can be interpreted as experience of individual beliefs in the non-physical (transcendent) dimension of life that describes the relationship between man and God and the various virtues that result from that relationship. There are at least five things implied in the terminology of spirituality as follows:

1. Connecting: relationships with God or supernatural powers, relationships with self, others, and the environment

2. Meaning (meaning): interpret life and find the purpose of its existence

3. Value (belief): belief in something that is valued, namely the necessity to do something right and good

4. Trancendence (transcendence): expression and appreciation of a dimension outside oneself; expand self-limits

5. Becoming (being): a self-raising that demands reflection and experience; includes who is someone's meaning, and how someone knows other things.

For pedicab drivers on the Trunojoyo road, the meaning of spirituality is connection and relationship with God or supernatural powers. The pedicab drivers believe in the existence of God Almighty. They often correlate the life lived by the will of Engkang Maha Kuaos (The Most Almighty). Supiyo, for example, a man from the sub-district of Lamongan Regency, said that he had been a becak driver since 1986 in Surabaya and in 2000 he moved to Bojonegoro until now.

For Supiyo and his friends, working as pedicab drivers is the will of the Almighty that they cannot refuse. Before being a pedicab driver, Supiyo helped his uncle who works as a collector 
of used goods, but it did not last long. Likewise, for Jajat, being a pedicab driver for him is a destiny determined by God. If he is now a night masseur and sleeping in a shop with his friends, pedicab drivers are due to his blurred vision. He said, "menawi mboten kranten mripat kulo mbolok'en nek siang, kulo tasik remen mbecak" (if it wasn't for my eyesight problem during the daytime, I would still like to pedal a pedicab).

In addition, the value is also the inner meaning of spirituality possessed by pedicab drivers at the Trunojoyo street. Becoming a pedicab driver is self-respect, because working is better than being unemployed, let alone being the head of the household. There is shame as man if only someone else sees it. There is an unspoken rule from Javanese tradition that require men to work and to be responsible for their families.

\section{The need for spirituality}

Spiritual needs are the highest human needs (Prijosaksono and Erningpraja: 2003). Based on the order of basic needs, biological elements rank first, then continue higher which is related to psychological elements, and the highest is spiritual needs. The relationship between pedicab drivers and God is a personal relationship to the transcendental One who has non-physical strength beyond human strength and has regulated everything in the world. Pedicab drivers, through the normative teachings of religion, also know that life is worship. Such beliefs provide strength and hope for individuals in their lives and can make individual life meaningful (Montahar, 2010). A meaningful life is a life that has found meaning and purpose, and this is a basic spiritual need for humans (Hawari, 2001: 27).

Nevertheless, the unique thing is that the need for increased faith and supervision of the weakening of the faith has received little attention from the pedicab drivers. They interpret God's relationship with humans as transcendental relationships so that they rarely follow activities that strengthen faith such as reciting the Quran. Yet, they are still praying, and fasting. These are instruments and the need for worship commitments and their relationship with everyday life, and integrative religious experience between ritual worship and experience in everyday life (Hawari, 2001: 33).

The highest spiritual requirements of pedicab drivers at the Trunojoyo street are actually in the free needs of doing guilt and sin against oneself and others. Kusiran (59 years old) relates that he was jailed twice. The first jail was in 1982 because of murder accusation. He killed man whom he thought was doing affairs with his wife. He was sentenced 9 years imprisonment, but because of his good behavior in prison such as teaching recitation and becoming a prayer priest. Therefore, he got a remission and only expereinced a 4.5-year sentence in prison.

Kusiran said that in fact he "repented". He considered that his act of killing is wrong, but he did not feel deeply regret for his actions were based on truth. According to him, the man he killed was a puppeteer who interfered with his household midwife. Self-esteem for Kusiran is very important. What he did was a reaction which he said was a "test". Because he stated that 
he had never stolen, robbed, cheated or committed adultery. This is a need for self-acceptance and self-esteem (self acceptance and self esteem), because everyone wants to be respected, accepted, and recognized by their environment (Hawari, 2001: 56).

Feelings of guilt to others and God actually happened when Kusiran went to jail for the second time. What caused him go to jail according to him was unbelievable and misunderstanding. Once he came to his married wife's house carrying sickles (sharp weapon to find grass), but his wife thought he was about to hurt her husband, so his wife spontaneously tried to grab the sickle, while Kusiran tried to defend it. When they grab each other, the wife's finger hurts. Kusiran said, "niku kulo menyesal sanget" (I was very sorry for this).

Not only being hostile to his wife, his family and neighbors were also hostile. Out of prison in 2001, the driver from the district of Bangilan, Tuban district, settled in Bojonegoro as a pedicab driver and worked side by side by cleaning the house of an obstetrician every morning in the Sumbang Bojonegoro sub-district. Since then he has never returned to his native village and became a resident of Bojonegoro as well as the Identity Card shown to me. Her mother is paddy, her fields and gardens have been sold out by her children.

For other pedicab drivers who are still on good terms with their families, being separate with their wives, children and grandchildren is common. They call it ngemboro or going for a living. Like Supiyo, he only goes home if he already got 400 thousand rupiah a minimum salary duing a week or two weeks. Jajat and Kaelan also usually can not meet therir. Sometimes their children visit the storefront where they stay. The pedicab drivers thought their friends were their family, if anyone needed help, they would be happy to help each other.

The attitude of mutual dependence on others according to Hawari (2001:) includes basic human spiritual needs i.e., the need for security, the need for maintaining interaction with nature and fellow humans. Therefore, the relationship with the people around them should always be maintained. Humans also cannot be separated from their natural environment as their place of life. It's just that, like Kusiran, who has never returned to his village, he does not think about the security of the future. He said that even if he died on the street, someone would still bury him. While Jajat, Supiyo, Kaelan, Poniman, even though they have separated from each other, they keep saving and think that it will not always be pedaling a pedicab, they will stop and choose to live with their children. Assurance of the future is part of the basic spiritual needs of humans (Hawari, 2001: 56-61).

\section{Spiritual Dimension of Pedicab Drivers}

Individual spirituality is seen from their spirits, which gives a description of life and strength that develops in an individual. Therefore, it is always interesting and unique. In general, this spiritual dimension is divided into two; vertical dimensions and horizontal dimensions. The vertical dimension is the individual's relationship with his God, while the horizontal dimension is the relationship of the individual to himself, others and his environment. 


\section{Vertical Dimension}

There are three things that cover the vertical dimension in this discussion; the transcendent dimension that reflects the transcendental relationship of the individual with its creator, the meaning and purpose of life that describes the experience and practice of life, and awareness of tragic events. These three things are the vertical dimensions that look most prominently from the pedicab drivers.

\section{a. Transcendental dimension}

God who is often referred to by the pedicab drivers as Engkang Maha Kuaos is The transcendent figure who has the authority to regulate this life. This belief in God plays a role in looking at the reality of life. When telling about his "choice" to be a pedicab driver that requires staying at the shops, generally the pedicab drivers see it from the point of view of destiny. Often the word Kersanipun crank kuaos (the Will of the Almighty) is juxtaposed with the word crank damel kerso (the Most Willing) said as an expression that whatever happens, such as their work as pedicab drivers, is a condition that must be accepted with legowo. According to Santosa (2012), Javanese have views and beliefs that the transcendent dimension of their lives is God.

For Kaelan, who is already 63 years old, the job of being a pedicab driver is work that is suitable for his ability. He thinks realistically. There is no other job that he thinks is comfortable and capable of doing. So he has been a pedicab driver for 29 years, from 1986 until now in 2015. By being a pedicab driver, he was able to raise five children who are now married all.

Kaelan's attitude is called realistic acceptance: realistic means the ability to be able to feel that something really exists. Acceptance means a positive attitude that someone shows towards something. So that realistic acceptance here means a positive attitude that is shown by someone towards their feelings and experiences of existence and their relationship with God

In life, Kaelan said to always be positive. He and his friends felt that being a pedicab driver from year to year was increasingly difficult. Because more and more means of transportation. Almost everyone uses a private motor vehicle. However, he and his friends were convinced that Allah was in control of sustenance. According to him, there are only people who need pedicab transportation facilities. The least income, if it is quiet, is 25 thousand rupiah. The money is used for perfunctory food, the most important according to him, life is lived alone and does not need to be adventurous (various).

Indeed there are expressions that show an attitude of "disappointed" with the situation. As Supiyo and Jajat said, "Rego Sakniki is so sedentary, but the pedicab is crunching, sego pecel, the mawon sakniki is 5 thousand" (the price is now rising, but (services) the becak (price) is fixed, pecel rice with tempeh and peyek just now 5 thousand rupiah). Therefore, to eat, they are forced to save a lot. However, the complaint complained with the words, "but thank God ..." (but (with all that) thank God).

Teosofia: Indonesian Journal of Islamic Mysticism, Volume 7, Number 1, 2019 
In the spiritual vertical sub dimension there is an element called disappointment, namely the ability to accept disappointment with God and remain in fellowship with God. Understanding psychologically disappointed is a failure of an expectation or desire that is not fulfilled. So, the pedicab drivers, even though they are in a state of disappointment, still believe that it is the will of God who has certainly chosen the best for him.

Disappointment that arises does not result in instability i.e., having difficulty in believing and seeing God as something that loves. This means that the pedicab drivers do not have a fixed tendency in their attitude. Sometimes someone has an attitude that believes that God loves him, but in other conditions a person might see God not love him.

\section{b. Meaning and Purpose of Their Lives}

In general, pedicab drivers believe that life after death. But each pedicab driver has a different view of the meaning and purpose of life. Jajat for example, his last education only graduated from elementary school (SD), but since childhood he has studied safinah in the musholla and has been a khadam (servant) in a boarding school for five years. He stated that the loss would be if living in the world only pursued the world. Life after death will be much longer. That is why he does not abandon religious obligations.

While Supiyo, did not graduate from elementary school, according to his friends he was an honest and sincere person. Do not hesitate to help their friends who have economic difficulties. For Supiyo, life is more beautiful when sharing. Compared to his friends, Supiyo's income was the biggest in a day because of his hard work. If he gets 50 thousand a day, he continues to serve and look for passengers, while his friends feel more than enough if they get 50 thousand a day. That is why he returned to the village most often, because sometimes not a week had been able to collect 400 thousand to be handed over by his wife and child. And only Supiyo who has a cellphone as a means of communication with the family. For him, family is everything. If the child asks him to go home because of homesickness, this one-child father will go home soon.

The meaning and purpose of life was different, it was shown by Kusiran who had been in prison. For him, life is over. He felt that there would be an end to hell that awaited him, because his doing killed people. Jajat and his friends have often advised that ugliness will be erased with kindness. However, as a graduate of Madrasah Tsanawiyah who is good at reciting and reading Arabic books and already has these grandchildren, he always says, "I want quality, you need advice!" (I already have grandchildren, don't need advice).

Jajat said that after Kusiran left the Penitentiary for the first time, many prison officials asked Kusiran to teach their children to recite. But since he was imprisoned for the second time in 7 months and "rejection" of people in his village, Kusiran no longer taught recitation and chose to live on the streets as a pedicab driver. 
The difference in the meaning and purpose of each individual's life is not only determined by the educational background but also determined by life experience and the search process and the level of understanding of the meaning and purpose of life. Overall it can be concluded that every individual wants to achieve each existence by living a meaningful and purposeful life.

\section{c. Awareness of Tragic Events}

Almost all pedicab drivers on the Trunojoyo road have experienced events that have caused suffering, the cases are almost the same; cheating wife. Jajat explained that the cause was that his wife and children were often left in the village, while they made a living in the city. The pedicab drivers are aware of that, but working to leave family must be done because of inadequate village income. The rice fields in the village are not large and only produce once a year.

Most of them responded to the incident with a religious and common sense perspective, except Kusiran who later committed a criminal act. Jajat stated that anger was natural, but for what dragged on, let alone commit crimes by eliminating people's lives. He said, "how come dadi begal nyawane is a God" (Why must be the usurper that Allah has). The important thing according to them is that as long as they are pedicab drivers, they never cheat. If a wife does so, God will reward her in the end.

The pedicab drivers continued to assess the incident with the path God had outlined to them. In Javanese life, tragedy is considered a reminder to the Kholik. The events of the wife's affair made them finally focus more on working to raise children and deliver them to marriage. Jajat, Supiyo and Kaelan have married all of their children, while Poniman, the only child, is still in high school. Whereas Kusiran did not want to connect with his children because according to him, he did not respect himself, that is when his son and ex-wife sold rice fields inherited from his grandmother. Several times his children came to stay in touch but were "expelled" by saying they did not need to be visited.

\section{Horizontal Dimensions}

The horizontal dimension is the relationship of individuals to themselves, others and their environment. A person must have knowledge about who he is and what he can do. Because someone's relationship with others and their environment is as important as themselves. The need to be a member of the community and mutual connectedness has long been recognized as a central part of human experience. Therefore building a harmonious relationship with oneself is also respecting good relations with others and the environment which in turn determines the appreciation of life and all that is associated with it.

\section{a. Material values (Material values)}

The pedicab drivers appreciate material like money. So they chose to work in a society that was no longer young. However, money is not everything. Their children who are married 
actually ask to stop pedaling a pedicab and stay with them, if only they eat and drink they can. However, for Jajat for example, work is not only a matter of mere money but also an activity that eliminates boredom. "Lha nek namung teng griyo, mangan turu, mangan turu, ngih bosen" (if at home our activities are just eating and sleeping, we are bored).

Unlike Jajat, who sees satisfaction not only from ownership of money, but with selfactualization, for the age Kaelan who has reached 63 years, it does not prevent him from continuing to work. Motivation to work is based on the principle of not wanting to trouble other people, and burdening their children. The grandfather of five grandchildren is happy if he can give something to his children and grandchildren. Javanese often mean "mbah" (grandfather) with "sing iso nambahi" (who can add). Kaelan said that as long as he was strong, he would still pedal the pedicab and live it happily. For several weeks now Kaelan has been in Cepu, Blora district, Central Java, to look for a "new atmosphere". By pedaling his rickshaw, Kaelan left the city of Bojonegoro towards Cepu, about 37 kilometers away.

Meanwhile Kusiran said that he never set prices. Lots of money and little should be seen as sustenance. So even if sometimes there are passengers who are not preceded by a price agreement and then pay a nominal value that is considered small, he chooses to remain silent rather than swear or demand exaggeration. The reason is because swearing and demanding it will reduce sustenance. Because according to Kusiran, if you swear at the actual passenger who is sworn by his sustenance and the giver of sustenance, namely Allah SWT itself. So that it will narrow the fortune.

The same thing also became Supi's view. Money is not always a top priority. So if there are people who need becak transportation services, even though it is late at night, even asleep and locking the rickshaw, he still serves. Because it is based on pity for the passengers. Although not so with Kaelan. If it is late at night and rest, he chooses not to serve passengers who need it. Because according to him, if lack of sleep, often the morning headache.

\section{b. Sacrifice (Altruism) and Togetherness}

Sacrifice and togetherness are dimensions of spirituality that cannot be separated from the pedicab pedestrian community on the Trunojoyo road. Each individual feels that he has a responsibility to give, take care of each other, please help, shoulder to shoulder, and return good favor.

Jajat said that when he was forced to stop being a pedicab driver because of eye pain, he then chose to become a masseur at night. His friends asked not to look for another place, but made the stores at the Trunojoyo street as places to serve massages. "Wes ning kene wae, wong kaet biyen ning kene, meh ning endi maneh? (Already, here only, after all here too, where are you going)," Jajat's friends said.

The feeling of suffering like other fellow pedicab rider was also experienced by Jajat by buying another pedicab from the massage. In fact, the pedicab was only parked in front of the 
store and was used as a place to store clothes. The purchase of a becak, in part, according to Jajat, came from a Supiyo loan. The pedicab he owned was sold for his eye treatment that had been not healed for so long.

Jajat also said that his friends often share food if there is sustenance. One of his friends named Sinyo was a pedicab driver who had been the "occupant" of a shop in the street Trunojoyo, but because he already had a house he no longer slept in a row, only almost every day at 10:00 a.m. to 1:00 a.m. he stopped by to accompany his friends, then go back home. According to Jajat, Sinyo did that because he had felt that he was sleeping together. There is a feeling of shared fate that brings awareness of the suffering of others.

Not surprisingly, the closeness between fellow pedicab drivers is like a family. When they come together for a break for lunch, they meet at one of the taverns in the town square of Bojonegoro. They are also open to each other so that each pedicab driver is very familiar with their fellows because there is nothing to cover up, in terms of personal and family problems. Everyone knows the history and life journey of his friends. Jajat said that at first they were still closed to each other, but over time, every problem was always told to their friends.

According to Santosa (2012) the nature of togetherness and sacrifice is the basic nature of Javanese who have the belief that with other people every human being lives life in the world, and from other people he gets sustenance. Many things in the world cannot be done (resolved) themselves so that they need the help of others. In line with the expression of the Javanese mung saderma anggadhuh peparinge Gusti Kang Akarya Jagad, which means "everything is only a gift, or a deposit".

\section{c. Concern for the environment}

Sleeping in a store does not make the pedicab drivers careless about the environment. Every morning, before the activity, everything has been cleared and cleaned instead. There is no garbage or things that make the surrounding shop dirty. The shop they live in is actually a shop house. Due to the shop owner also stays inside.

The shop owners, not only the emperors are used as a resting place, but also those around the Trunojoyo road know the pedicab drivers themselves. This shows good interaction between pedicab drivers and shop owners. Pedicab drivers also know the shop owner's family well. When I asked about the family of the shop owners, they told in detail how many children the shop owner is, who is now and what works.

This interaction also occurs because shop owners often ask the help of pedicab drivers to deliver their children or bring goods. Relations between shop owners and pedicab drivers are mutually helpful and profitable. The shop owners feel safe because there is already a "night watchman", while the pedicab drivers feel lucky because they get a "free" resting place.

\section{E. Factors Affecting the Spirituality of Pedicab Drivers}

Teosofia: Indonesian Journal of Islamic Mysticism, Volume 7, Number 1, 2019 
There are at least three main factors that influence the spirituality of pedicab drivers on the Trunojoyo road in Bojonegoro, i.e., of religious education, culture (ethnicity), and life experience. These three factors are mutually reinforcing; the higher the level of religious education of a person, the more colorful his life experience, and the stronger his hold on culture or customs, the more influential the high and low of his spirituality.

\section{Religious Education}

Religious education is a factor that influences the spirituality of the pedicab drivers. Jajat said that since childhood, his father was hard in religious education. He is often punished if he does not leave to recite the Qur'an and the books of aqeedah and morals in Musola. For five years he also became khadam (servant and not paid) in Islamic boarding schools, learning religious values such as serving others, being courageous, being humble, respecting the older, and so forth.

Not unlike Jajat, Kaelan and Supiyo often use religious terminology in interpreting life as reflected in words such as Engkang Maha Kuaos (Almighty), Engkang Ndamel Kerso (The Most Willing), tekdir (takdir) and others- other. The word bismillah is heard if you want to start an activity. Likewise the word Alhamdulillah was said when telling about pleasure.

Prof. Dr. Zakiah Darajat (2001: 38) says in his research religion influences people's attitudes and behaviors or mechanics that work in a person, because the way a person thinks, behaves, reacts and behaves is inseparable from his belief, because that belief is included in personal construction.

\section{Cultural Factors}

Culture has an important role in influencing one's spirituality since the spiritual dimension is an integral part of the culture of a society. The spirituality of the pedicab drivers influenced by Javanese culture is reflected in the many terms used, such as ora njowo, nrimo ing pandum, and urip plays. Said ora njowo interpreted as people who do not animate as Javanse people. This term is often referred to as "banter" for individuals who care less about social values as a horizontal dimension of spirituality. For example is indifference to the environment, not mutual tolerance, no respect for the older and so forth. According to Franz Magnis Suseno (1985: 227) this includes Javanese Ethics so that individuals do not harm the community so that individuals must maintain harmony.

The terms nrimo ing pandum and melu urip play are terms that show the vertical dimension of spirituality. Nrimo ing pandum can be interpreted simply by accepting sincerely what God has given. However, this Javanese philosophy is understood vaiously by the pedicab drivers. For Kasiran, the term means honesty. He told me that every morning he worked side-by-side to become a cleaner in a doctor's house, the food available at home was delicious and always abundant, but he never touched the slightest bit. As long as the host does not allow him to eat, he also never eats. According to him, his job is just cleaning, no more than that. 
Nrimo ing pandum meant by Jajat is an expression of patience and gratitude for whatever happens as part of the urip play (way of life). When his vision was dim, he had tried treatment, but the doctor stated that the disease was genetic and could not be cured. This pain was received without complaining and was not desperate in earning a living, so he switched from being a pedicab driver to a night masseur at the store. Several times Jajat stated that he actually still likes to be a pedicab driver, but in this life between hope and reality is not always accepted equally. There are always things you don't like.

Other pedicab drivers interpret nrimo ing pandum in harmony with qona'ah in religious terminology, which is to feel sufficient for the provision given by Allah SWT. By doing so, they do not demand excess to passengers. If asked how much it costs to go to one destination, they will mention the nominal, but if the passengers object, return it to the wishes of the passengers. If the passenger does not ask for the cost of travel, the pedicab drivers never charge a fee. If given a little accepted, and if given a lot of thanks. Because Javanese culture states that it is unethical to question sustenance.

\section{Life Experience Factors}

Positive (happy) and negative (sad) life experiences contribute to one's spirituality. Like Kusiran, his life is colored by negative experiences; once killed someone, had been imprisoned twice, was hurt, and rejected by his village community. Therefore it influences the relationship with oneself, with others and with God.

Against his Lord, Kusiran felt that hell in the end was waiting for him. This often leads to the view that his life is useless so he does not respect himself. Views of other people are also often negative, Kusiran always slips the clurit (sharp weapon) in his mind with a reason just in case of people trying to hurt him. Time and again the friends reminded them not to carry sharp weapons, but were ignored. But uniquely, Kusiran judged that what happened to him was a test, just like the prophet who also had a test.

Meanwhile, Jajat said that since he was a child he was used to living a difficult life, his siblings were seven and no one graduated from elementary school except himself. His father is a farmer. Like most farmers in the village, he and his brothers helped in the fields, looked for grass and grazed goats. Farmer's life is generally without significant turmoil. Economic difficulties are common. Therefore, the failure of the household Jajat due to his wife's affair is only considered as a way of life. There was no overflowing anger, disappointed for a while, but then thought there might also be an error from him, so that relations with ex-wives, children remained good, as also happened to Kaelan and Supiyo.

\section{F. Conclusion}

Pedicab drivers generally interpret spirituality with two elements found in spirituality terminology, namely connecting and value. Connecting for the pedicab drivers means the connection with their God who is believed to be His existence as a transcendent figure with

Teosofia: Indonesian Journal of Islamic Mysticism, Volume 7, Number 1, 2019 
supernatural powers. God for them is the Almighty at the same time the Most Willing. While value is the value of self that combines between feeling honored to be a pedicab driver for not being unemployed, and feeling ashamed as a man and head of the household, giving birth to an attitude of responsibility.

The connection of pedicab drivers and transcendent God figures is a basic spiritual need that has given them hope and strength in living their lives. Besides that, belief in the existence of life diherat; heaven and hell, bringing the highest basic spiritual needs, namely the desire to be free from guilt and sin, both to oneself and others. That is why people like Kusiran, who have committed crimes, still feel insecure and easily provoked by emotion.

The basic needs of spirituality in general are two dimensions of spirituality itself, namely vertical dimensions and horizontal dimensions. Vertically pedicab drivers believe that life as a pedicab driver is a destiny of the Most Willing that must be accepted by Legowo. They accept realistic (realistic acceptance) in living life and always be positive. Disappointment that arises because of reality that is not as expected, does not lead to instability, but remains in fellowship with God. So that on tragic events they are generally aware that this is only part of the play urip (Way of life).

The way of life of the pedicab drivers is full of meaning. They see loss if life is only pursuing material. Money for them is very valuable but not everything, they do not set fees and are always ready to deliver passengers even late at night on the grounds of compassion. They also view life without activities as boring so they refuse requests from their children to stop working because they are not young.

Living together on the street also gave birth to high solidarity among fellow pedicab drivers. Sincerely, sincerely and honestly they will help their friends who are in trouble, even though Kusiran, who has been imprisoned twice, and rejected by the residents of his village, life is no longer meaningful. But his strength of survival in the age of 59 years is due to the togetherness of fellow pedicab drivers who are like their own family. There is not one bit of the problem being covered up.

The level of spirituality possessed and demonstrated by the pedicab drivers at the Trunojoyo street in Bojonegoro City is due to several main factors, including the individual religious education, Javanese culture or customs that they live in and colorful life experiences.

\section{Bibliography}

Beyer, P. 2006. Religion in Global Society. London; New York: Routledge.

Bruinessen, M. v., \& Howell, J. D. (Eds.). 2008. Urban Sufism. Jakarta: Rajawali Press.

Carrette, J., \& King, R. 2005. Selling Spirituality, the Silent Takeover of Religion. London and New York: Routledge. 
Casanova, J. 1994. Public Religions in the Modern World. Chicago: University of Chicago Press.

Compte-Spoville, A. 2007. Spiritualitas Tanpa Tuhan (U. Tauhida, Trans.). Jakarta: Alvabet.

Danarto. 1996. Gerak Gerik Allah: Sejumput Hikmah Spiritual. Surabaya: Risalah Gusti.

Daradjat, Zakiyah. 2001. Peranan Agama dalam Kesehatan Mental. Jakarta: PT Toko Gunung Agung.

Dyer, W. W. 2005. There is a Spiritual Solution to Every Problem. Jakarta: Gramedia Pustaka Utama.

Gibson, Ivancevich, and Donnely. 2003. Organisasi dan Manajemen: Perilaku Struktur. Jakarta: Erlangga.

Hawari, Dadang. 1998. Al-Qur'an, Ilmu Kedokteran Jiwa dan Kesehatan Jiwa. Yogyakarta: PT. Dana Bhakti Primayasa. 2001. Manajemen Stres Cemas dan Depresi. Jakarta: Balai Penerbit FKUI.

Mubarok, Achmad. 2000. Jiwa dalam al-Qur'an; Solusi Krisis Keruhanian Manusia Modern. Jakarta: Paramadina.

Santosa, Imam Budhi. 2012. Spiritualisme Jawa, Sejarah, Laku, Dan Intisari Ajaran.Yogyakarta: Memayu Publishing.

Smith, Uriah. 1896. Modern Spiritualism: a Subject of Prophecy and a Sign of The Times. Michigan: Herald Publishing.

Teosofia: Indonesian Journal of Islamic Mysticism, Volume 7, Number 1, 2019 